\title{
Further Evidence on Asymmetry in the Impact of Oil Price on Exchange Rate and Stock Price in China using Daily Data
}

\author{
Nazeer Ahmed ${ }^{1}$, Ma Dingchou ${ }^{1} \&$ Abdul Qayyum ${ }^{2}$ \\ ${ }^{1}$ College of Finance and Economics, Gansu Agricultural University, Lanzhou, China \\ ${ }^{2}$ Department of Economics, University of Turbat, Pakistan \\ Correspondence: Ma Dingchou, College of Finance and Economics, Gansu Agricultural University, Lanzhou, \\ China. E-mail: madc@gsau.edu.cn
}

Received: March 13, 2021

Accepted: April 9, 2021

Online Published: April 12, 2021

doi:10.5539/ijef.v13n5p83

URL: https://doi.org/10.5539/ijef.v13n5p83

\begin{abstract}
The role of oil price on the macro-economy has been intensely researched. However, oil remains one of the most important energy sources for production. Concerning China, there are projections that the country's energy consumption would have risen to 18 billion barrels per day in the next two decades. Given China's heavy reliance on oil, we reexamine the impact of oil price on the US dollar-Renminbi rate and the Shanghai index using daily data from 4/01/2010 to 29/03/2021. In our analysis, we apply the Nonlinear ARDL technique in the presence of structural breaks and find that oil price has asymmetric impact on exchange rate and stock price in the short-run alone. However, the asymmetry is only in terms of magnitude and not in terms of effect direction. Oil price is found to appreciate the Renminbi vis-à-vis the US dollar and to increase stock price significantly both in the short-run. We find that accounting for structural breaks is necessary for cointegration in using oil price to explain both variables.
\end{abstract}

Keywords: asymmetric effects, NARDL, structural breaks

\section{Introduction}

The impact of oil price on the domestic economy has been an intensely researched issues over the years. The underlying rationale behind these researches is that energy is indispensable, and even irreplaceable as a production input (Bjørnland, 2009). Given its importance, energy price movements tend to have a substantial impact on macroeconomic outcomes owing to their influences on production cost and output prices (Bohi, 1989). Among the variables frequently affected by oil price variations are exchange rate and stock price (Salisu \& Oloko, 2015; Kumar, 2019). One theoretical explanation for how oil price affects exchange rate suggests that wealth is transferred from the oil-consuming country to the oil-producing country when oil price increases (Bénassy-Quéré, Mignon, \& Penot, 2007). This occurs because the increased oil price means that the same quantity of oil is purchased with more of the oil consumer's currency thereby improving the oil producer's balance of payment (Beckmann, Czudaj, \& Arora, 2017). According to another explanation, an oil price rise would make the net oil-importer's exports less competitive if its traded sector is energy-intensive, thus leading to a currency depreciation for the oil importer (Amano \& van Norden, 1998). The previous explanations, known respectively as the wealth and terms-of-trade effects imply that a net oil-importing country would always experience a currency depreciation when oil price increases. These explanations were modified in a later proposition which stated that the currency depreciation resulting from an oil price increase is more certain for the net oil-exporter in the short-run given rigidities in tastes and production techniques (Beckmann \& Czudaj, 2013). Over the long-run, it is possible that residents in both net oil-importing and net oil-exporting countries show a greater preference for the securities of the latter country, such that the wealth and terms-of-trade effects are eliminated. This explanation, known as the portfolio reallocation hypothesis suggests that the long-term impact of oil price changes on exchange rate is tied to portfolio preferences and reallocation between the net oil-importer and net oil-exporter. Indeed, the implicit suggestion is that net oil-producing countries are mostly unindustrialized, having undeveloped and unstable financial systems. Therefore, their residents should exhibit a greater preference for financial investments in the mostly industrialized, net oil-importing countries. This proposition implies that the net oil-importer's currency could appreciate in the long-term for an oil price increase, a possibility that was not mentioned in the earlier explanations (Beckmann et al., 2017). 
A look at the empirical literature on oil price's effect on the exchange rate of net-oil importing countries shows mixed evidences but the support for theoretical postulations has been overwhelming (e.g., Faria, Mollick, Albuquerque, \& León-Ledesma, 2009; Ou, Zhang, \& Wang, 2012; Qianqian 2011; Ju, Zhou, Zhou, \& Wu, 2014; Bai \& Koong 2018; Khraief, Shahbaz, \& Mahalik, 2021; Nazeer, Dingchou, \& Onodje, 2021 all covering China; Amano \& van Norden, 1998; Bénassy-Quéré et al., 2007; Lizardo \& Mollick, 2010; Turhan, Sensoy, \& Hacihasanoglu, 2014 all covering the US). In the case of net-oil exporting countries, the empirical evidence has also been mixed with some studies conforming with the theory (e.g., Olomola \& Adejumo, 2006; Suleiman \& Mohammad, 2011; Adeniyi, Omisakin, Olusegun, \& Oyinlola, 2012 all covering Nigeria; Hasanoy \& Samadoya, 2010 covering Azerbaijan; Jahan-Pavar and Mohannadi, 2011 for Angola \& Nigeria; Tiwari, Matascu, \& Albulescu, 2013 covering Romania) and others contradicting the theory (e.g., Rautava, 2004 covering Russia; Katun \& Wyzan, 2005 covering Kazakhstan; Benhabib, Kamel, \& Maliki, 2014 covering Algeria). These mixed evidences on oil price's impact on exchange rate documented for both country types have been attributed to several factors, including methodological differences, exogenous shocks, and policy dynamics which has capacity to alter the observed oil price-exchange rate relationship (Qiang et al., 2019).

In terms of how oil price could influence the stock market the most obvious explanation is that companies' production costs vary directly with oil price changes. Under the assumption of efficient markets, all information about a firm' prospect and value are reflected in its stock price. If that is the case, then present and future impacts of oil price changes would reflect fully on stock prices (Bjørnland, 2009). Moreover, stock prices represent the discounted values of firms' present and future net profits (Wei \& Guo, 2017). Since oil price affects production cost, an oil price increase should cause expected profits to fall and stock prices to decrease consequently (Basher, Haug, \& Sadorsky, 2012; Kumar, 2019). The theoretical proposition concerning how stock prices respond to oil price changes has not be met with consistent empirical results whether for net oil-consuming or net oil-producing countries. Taking the US as an example of net oil-importing countries, various studies document that stock prices decline significantly when oil prices rise (e.g., Jones \& Kaul, 1996; Ghouri, 2006; Nandha \& Faff, 2008; Elyasiani, Mansur, \& Odusami, 2012; Kang, Ratti, \& Yoon, 2014; Lambertides, Savva, \& Tsouknidis, 2017; Sakaki, 2019) while others find evidence of a positive relationship (e.g., Al-Mudhaf \& Goodwin, 1993; Kilian \& Park, 2009; Mollick \& Assefa, 2013). Taking China as an example, a substantial part of the empirical evidence contradicts the theory (e.g., Lin, Fang, \& Cheng, 2010; Zhang \& Chen, 2011; Zhu, Su, Guo, \& Ren, 2016; Wei \& Guo, 2017; Bai \& Koong, 2018; Tian, Li, \& Wen, 2021). Using techniques that capture time-varying associations, some studies report that the impact direction of oil price on China stock prices have been dynamic over time (e.g., Broadstock \& Filis, 2014; Caporale, Ali, \& Spagnolo, 2015; Xiao, Zhou, Wen, \& Wen, 2018; Wei, Qin, Li, Zhu, $\&$ Wei, 2019). In the net oil-exporting countries some evidences are in favour of the theory (e.g., Filis, Degiannakis, \& Floros, 2011; Wang, Wu, \& Yang, 2013; Filis \& Chatziantoniou, 2014). Bjørnland (2009) however, document that oil price shocks have a positive impact on the Norwegian stock market. Recently, Mokni (2020) found evidence of a predominantly positive relationship between oil price and stock prices of several net oil-exporting countries, including Mexico, Russia, and Venezuela.

These mixed results on oil price's influence on macroeconomic magnitudes is a key motivating factor for the ongoing research around this topic particularly as new methodologies are being developed and popularized. Moreover, crude oil remains the most utilized energy source for production and transportation (IEA, 2020) despite an increasing popularity of the "green movement" and the drive towards sustainable energy. Recent projections affirm that global crude oil consumption is growing and would continue to do so at an average of 950 thousand barrels per day annually over the 2019-25 period (Ritchie \& Roser, 2020). In China alone, per capita oil consumption is close to $33 \%$ of OECD countries combined. An examination of the historical data reveals that oil consumption in China has grown over the past two decades from 4.7 million to 14.1 million barrels per day and will expand further to nearly 18 million barrels per day by 2040 (Meidan, 2020). These projections are a strong indication that oil price would continue to exert a heavy influence on China's economy, including in her exchange rate and stock markets in the foreseeable future. Based on these expectations, we revisit the role of oil price on the US dollar-renminbi rate and the Shanghai index. Some previous studies examined oil price's role on exchange rate and stock prices in China but none, with the exception of Nazeer et al. (2021), investigated shortand long-run asymmetries in oil price's impact on these variables. Unlike Nazeer et al. (2021), we apply daily data to accommodate greater dynamics in the data generation and extend our data to recent periods. The rest of this paper is structured as follows. Section 2 discusses the data and sources and outlines the methodological strategy. In Section 3 we perform preliminary analysis on the data and present the main results with discussions. Section 4 concludes the paper with final comments. 


\section{Data and Methodology}

For the purpose of this study, we utilize daily data from 4 January 2010 to 29 March 2021 on the US dollar-RMB exchange rate and the Shanghai stock index and use WTI prices to measure oil price. Data for the US dollar-RMB rate and the Shanghai index are obtained from the investing.com site while data for WTI price is obtained from the International Energy Agency (IEA) website. All data are transformed to natural log form to normalize and for ease of interpretation. In order to examine asymmetry in the effect of oil price on both markets we rely on the Nonlinear ARDL (NARDL) technique by Shin et al. (2014) which decomposes oil price's effect in to negative and positive effects. The idea of modelling asymmetries in the impact of oil price on macroeconomic magnitudes date back to Mork (1989) with later variants proposed by other scholars (e.g., Hamilton, 1989; Lee et al., 1995; Hamilton, 2003; Kilian, 2009). In the Mork specification, which this study adopts, a positive oil price change is computed as follows.

$$
o p_{t}^{+}=\sum_{i=1}^{t} \max [\Delta o p, o]=\sum_{i=1}^{t} \Delta o p_{t}^{+}
$$

A negative oil price change is computed similarly in the following manner.

$$
o p_{t}^{-}=\sum_{i=1}^{t} \max [\Delta o p, o]=\sum_{i=1}^{t} \Delta o p_{t}^{-}
$$

In equations (1) and (2) $o p_{t}^{+}$and $o p_{t}^{-}$are respectively positive and negative log oil price (op) changes per period which are respectively computed as the cumulative sums of positive and negative changes in the variable from the original data. The NARDL model in this case would assume the following form for the exchange rate model.

$$
\begin{gathered}
\Delta e x_{t}=\beta_{01}+\sum_{i=0}^{p} \beta_{11 j} \Delta e x_{t}+\sum_{i=1}^{q} \beta_{21 i} \Delta o p_{t}^{+}+\sum_{i=1}^{q} \beta_{31 i} \Delta o p_{t}^{-}+\rho_{1} e x_{t-1}+\alpha_{11} o p_{t}^{+} \\
+\alpha_{12} o p_{t}^{+}+\eta_{1 t}
\end{gathered}
$$

The model for stock price is likewise specified in the following way.

$$
\begin{gathered}
\Delta s p_{t}=\beta_{02}+\sum_{i=0}^{p} \beta_{12 j} \Delta s p_{t}+\sum_{i=1}^{q} \beta_{22 i} \Delta o p_{t}^{+}+\sum_{i=1}^{q} \beta_{32 i} \Delta o p_{t}^{-}+\rho_{2} s p_{t-1}+\alpha_{12} o p_{t}^{+} \\
+\alpha_{22} o p_{t}^{+}+\eta_{2 t}
\end{gathered}
$$

ex and sp in equations (3) and (4) respectively denote log exchange rate and log stock price. Both models can be reparametrized in the following way to show the Error Correction Term (ECT) whose parameter depicts the speed of adjustment when there is a short-run shock in the model.

$$
\begin{aligned}
& \Delta e x_{t}=\sum_{i=0}^{p} \beta_{11 j} \Delta e x_{t}+\sum_{i=1}^{q} \beta_{21 l} \Delta o p_{t}^{+}+\sum_{i=1}^{q} \beta_{31 l} \Delta o p_{t}^{-}+\rho_{1} E C T_{1}+\eta_{1 t} \\
& \Delta s p_{t}=\sum_{i=0}^{p} \beta_{12 j} \Delta s p_{t}+\sum_{i=1}^{q} \beta_{22 l} \Delta o p_{t}^{+}+\sum_{i=1}^{q} \beta_{32 l} \Delta o p_{t}^{-}+\rho_{2} E C T_{2}+\eta_{2 t}
\end{aligned}
$$

The ECT in both cases are calculated from the following expressions.

$$
\begin{aligned}
& \rho_{1} E C T_{1}=\rho_{1}\left(e x_{t-1}-\alpha_{11}^{*} o p_{t}^{+}-\alpha_{12}^{*} o p_{t}^{+}\right) \\
& \rho_{2} E C T_{2}=\rho_{2}\left(s p_{t-1}-\alpha_{21}^{*} o p_{t}^{+}-\alpha_{22}^{*} o p_{t}^{+}\right)
\end{aligned}
$$

The short-run parameters, found in equations (3) to (6) are $\beta_{11 j}$ and $\beta_{21 j}$ for the exchange rate model and $\beta_{12 j}$ and $\beta_{22 j}$ for the stock price model. The long-run parameters are actually $\alpha_{11}^{*}$ and $\alpha_{12}^{*}$ for the exchange rate model, and $\alpha_{21}^{*}$ and $\alpha_{22}^{*}$ for the stock price model which are given by, $\alpha_{11}^{*}=-\alpha_{11} / \rho_{1}, \alpha_{12}^{*}=-\alpha_{12} / \rho_{1}$, $\alpha_{21}^{*}=-\alpha_{21} / \rho_{2}$, and $\alpha_{22}^{*}=-\alpha_{22} / \rho_{2}$. To test for asymmetric effects, the following hypotheses using

Wald-based F-tests were suggested by Shin et al. (2014): $-\frac{\alpha_{11}}{\rho_{1}}=-\frac{\alpha_{12}}{\rho_{1}}$ for the exchange rate model and $-\frac{\alpha_{21}}{\rho_{2}}=-\frac{\alpha_{22}}{\rho_{2}}$ for the stock price model. Correspondingly, the short-run asymmetric tests are tested using the following hypotheses: $\sum_{i=1}^{q} \beta_{21 l}=\sum_{i=1}^{q} \beta_{31 l}$ for the exchange rate model and $\sum_{i=1}^{q} \beta_{22 l}=\sum_{i=1}^{q} \beta_{32 l}$ for the stock price model. Table 1 shows the summary statistics of the variables. 
Table 1. Summary statistic table

\begin{tabular}{lccc}
\hline Statistic & Log exchange rate & Log Stock Price & Log Oil Price \\
\hline Mean & 1.877 & 7.935 & 4.175 \\
Median & 1.875 & 7.972 & 4.162 \\
Maximum & 1.971 & 8.550 & 4.731 \\
Minimum & 1.799 & 7.576 & 2.187 \\
Std. Dev. & 0.045 & 0.182 & 0.363 \\
Skewness & 0.124 & -0.020 & -0.596 \\
Kurtosis & 1.792 & 2.750 & 3.438 \\
Jarque-Bera & 185.536 & 7.790 & 196.500 \\
Probability & 0.000 & 0.020 & 0.000 \\
Observations & 2927 & 2927 & 2927 \\
\hline
\end{tabular}

\section{Analysis and Discussion}

\subsection{Preliminary Analysis}

The graphical representation of the variables' evolution over the analysis period is presented in Figure 1. We see that all the variables exhibit a pattern of fluctuation during the analysis period. Log exchange rates exhibit a downward trend for most of the periods before 2015 but start an upward trend up till around 2017. Recently, the downward trend can be observed from around mid-2020. A strikingly similar movement pattern to exchange rate can be observed for stock price particularly in the post-2015 periods. The peak of log stock price can be observed around mid-2015 which is followed by a declining pattern up till after 2016 when it stabilized somewhat. Concerning log oil price, substantial changes in its movement pattern occurred around late 2014 owing largely to the supply glut and the US shale oil production boom. Generally, there are some visible pattern changes in all variables since 2020 following the Corona virus outbreak. The slump in oil prices after production shutdowns in the industrialized economies is particularly notable and so is the renminbi's gain vis-à-vis the US dollar.
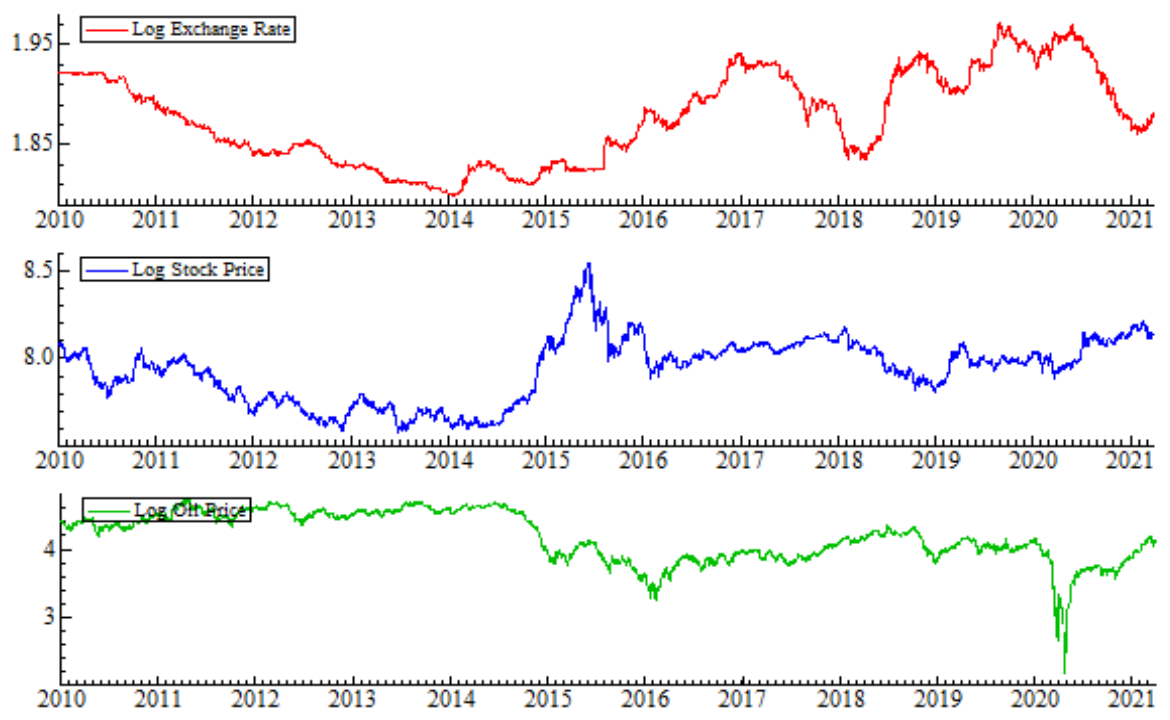

Figure 1. Time plot of variables

Unit root tests were performed on the tables using the augmented Dicky-Fuller (ADF) and Phillips-Perron tests and the test results are summarized in Table 2. According to the ADF test results, log exchange rate and log stock price are not stationary at levels whereas, log oil price is levels-stationary. This results are replicated by the PP test results. The conclusion for both set of tests confirm that both dependent variables (exchange rate and stock prices) are $\mathrm{I}(1)$ series whereas the independent variable (oil price) is an $\mathrm{I}(0)$ series. 
Table 2. Unit Root Test results

\begin{tabular}{llll}
\hline Series & Levels & Difference & Stationarity \\
\hline Augmented Dickey-Fuller & & & \\
Log Exchange Rate & $-1.46(0.84)$ & $-24.69(0.00)$ & $\mathrm{I}(1)$ \\
Log Stock Price & $-2.67(0.25)$ & $-20.88(0.00)$ & $\mathrm{I}(1)$ \\
Log Oil Price & $-5.81(0.00)$ & $-23.58(0.00)$ & $\mathrm{I}(0)$ \\
Phillips-Perron & & & \\
Log Exchange Rate & $-2.05(0.59)$ & $-42.65(0.00)$ & $\mathrm{I}(1)$ \\
Log Stock Price & $-3.61(0.03)$ & $-43.31(0.00)$ & $\mathrm{I}(0)$ \\
Log Oil Price & $-4.32(0.00)$ & $-58.09(0.00)$ & $\mathrm{I}(0)$ \\
\hline
\end{tabular}

Note. p-values of test statistics in parentheses.

A visual inspection of log exchange rate and log stock price in Figure 1 suggests that the time paths of both series could have been altered significantly following some exogenous events. If these shifts in the time paths of the variables are not accounted for, there is tendency for errors to occur in explaining their long-run manifestations. To circumvent such errors, we apply the Bai and Perron (BP, 2003) test that accommodates up to 5 breaks. The result of the sequential $L+1$ versus $L$ breaks is summarized in Table 3 along with the estimated break dates. According to the results, both variables experienced 4 structural breaks during the analysis period. The break dates for both series are also strikingly similar which is not surprising given that both series are exposed to the same macroeconomic shocks.

Table 3. Bai-Perron structural break test results

\begin{tabular}{lccc}
\hline Hypothesized & \multicolumn{3}{c}{ F-Statistics } \\
\cline { 2 - 4 } Breaks & Log Exchange Rate & Log Stock Price & 8.58 \\
\hline 0 not 1 & 2512.32 & 3429.97 & 10.13 \\
1 not 2 & 2699.72 & 3481.009 & 11.14 \\
2 not 3 & 365.22 & 344.193 & 11.83 \\
3 not 4 & 138.04 & 28.73925 & 12.25 \\
4 not 5 & 0.000 & 0.000 & \\
\hline \multicolumn{5}{c}{ Estimated Break Dates } \\
\end{tabular}

\subsection{Asymmetric Impact of Oil Price on Exchange Rate and Stock Price}

In order to examine how oil price affects exchange rate, we implement the NARDL model for both series. We estimate two models in each case, one that accounts for structural breaks and one that doesn't. Table 4 summarizes the models with structural breaks for both variables. The coefficients and t-statistics are shown in both instances. At a glance, we see that oil price does not significantly influence both markets in the long-run as neither of the long-run coefficients are significant in both cases. We also observe that oil price's long-run impact on exchange rate is positive but its long-run impact on stock price is negative. While these estimates are not statistically significant, they do follow the theoretical predictions in part. Being a net oil consumer, China's currency should depreciate vis-à-vis the US dollar due to loss in competitiveness resulting from higher export costs when oil price increases. Similarly, a higher oil price implies greater production costs which decreases expected profits and firms' stocks. Turning to the short-run estimates, an oil price increase or decrease reduce exchange rate but increase stock price. These results partly run contrary to theory in both cases since we expect an oil price increase to depreciate the RMB and decrease stock price and an oil price decrease to appreciate the Renminbi and increase oil price. On the contrary, the results show that exchange rate would appreciate for a short-run oil price change whether positive or negative and that stock price would rise regardless of whether oil price rises or decreases. The bounds tests confirm significant cointegration in both models despite the insignificant long-run estimates. Concerning asymmetry, the evidence shows that oil price's effect on exchange rate differs between positive and negative oil price changes. But this difference is mainly in magnitude terms since the coefficients of positive and negative oil price changes have the same signs. The same pattern is observed for the short-run asymmetry test in the exchange rate model. In the stock price model, there is no evidence that oil price has an asymmetric impact whether in the short- or long-run. 
Table 4. Estimated NARDL equations with breaks

\begin{tabular}{|c|c|c|c|c|c|}
\hline \multirow{2}{*}{ Variables } & \multicolumn{3}{|c|}{ Log Exchange Rate } & \multicolumn{2}{|c|}{ Log Stock Price } \\
\hline & Coefficient. & & $t$-Statistic & Coefficient. & $t$-Statistic \\
\hline \multicolumn{6}{|l|}{ Long-run } \\
\hline & $o p^{+}$ & 0.066 & 0.519 & -0.012 & -0.085 \\
\hline & $o p^{-}$ & 0.083 & 0.637 & -0.014 & -0.096 \\
\hline \multicolumn{6}{|l|}{ Short-run } \\
\hline & $\Delta e x(-1)$ & -0.037 & $-2.003 * *$ & - & - \\
\hline & $\Delta o p^{+}$ & -0.007 & $-3.036^{* * *}$ & 0.039 & $2.643 * * *$ \\
\hline & $\Delta o p^{+}(-1)$ & - & - & 0.037 & $2.471 * *$ \\
\hline & $\Delta o p^{-}$ & -0.005 & $-3.293^{* * *}$ & 0.036 & $3.213 * * *$ \\
\hline & $\Delta o p^{-}(-1)$ & -0.007 & $-4.146^{* * *}$ & 0.044 & $3.493 * * *$ \\
\hline & $\Delta o p^{-}(-2)$ & 0.0002 & 0.146 & 0.023 & $1.899^{*}$ \\
\hline & $\Delta o p^{-}(-3)$ & -0.005 & $-2.867 * * *$ & - & - \\
\hline & $\operatorname{ECT}(-1)$ & -0.004 & $-5.127 * * *$ & -0.012 & $-4.806 * * *$ \\
\hline Breaks & \multicolumn{3}{|l|}{ Yes } & \multicolumn{2}{|l|}{ Yes } \\
\hline Bounds F & \multicolumn{3}{|l|}{$6.565 * * *$} & \multicolumn{2}{|l|}{$5.767 * * *$} \\
\hline Long-run asymmetry $\mathrm{F}$ & \multicolumn{3}{|l|}{$5.579 * *$} & \multicolumn{2}{|l|}{1.744} \\
\hline Short-run asymmetry F & \multicolumn{3}{|l|}{$10.567 * * *$} & \multicolumn{2}{|l|}{0.971} \\
\hline B-G LM test & \multicolumn{3}{|l|}{0.146} & \multicolumn{2}{|l|}{2.193} \\
\hline B-P test & \multicolumn{3}{|l|}{$130.95 * * *$} & \multicolumn{2}{|l|}{$266.176 * * *$} \\
\hline RESET & \multicolumn{3}{|l|}{0.754} & \multicolumn{2}{|l|}{0.144} \\
\hline CUSUM & \multicolumn{3}{|l|}{ Stable } & \multicolumn{2}{|l|}{ Unstable } \\
\hline CUSUM Squares & \multicolumn{3}{|l|}{ Stable } & \multicolumn{2}{|l|}{ Stable } \\
\hline
\end{tabular}

Note. B-G LM is Breusch-Godfrey LM autocorrelation test. B-P test is Breusch-Pagan heteroskedasticity test. HAC standard errors used. $*, * *, \& * * *$ respectively mean significance at $10 \%, 5 \%, \& 1 \%$.

In Table 4, the estimated NARDL models without breaks have been reported. The results are strikingly similar to the previous results with breaks. For instance, oil price's long-run impact on exchange rate and stock price is positive and negative respectively regardless of oil price's change direction. In addition, oil price's effect in both models is insignificant at the 5\% level. Again, the long-run results obtained in Table 5 are partly in line with the theoretical expectations although insignificant at acceptable levels. Expectedly, when oil price increases, exchange rate would depreciate and stock price would decrease, but insignificantly in the long-run. The short-run estimates suggest that exchange rate would appreciate and stock price would rise significantly regardless of what happens to oil price as found in Table 4. Table 5 results differ from the previous result in that the bounds test found no evidence cointegration in both models. Also, an evidence of asymmetry in oil price's effect is lacking in both long-run models but present in both short-run models. Given that the oil price's coefficient for negative and positive changes in both short-run models have the same signs, the short-run asymmetry is in terms of magnitude and sign direction.

Table 5. Estimated NARDL equations without breaks

\begin{tabular}{|c|c|c|c|c|c|}
\hline \multirow{2}{*}{ Variables } & & \multicolumn{2}{|l|}{ Log Exchange Rate } & \multicolumn{2}{|c|}{ Log Stock Price } \\
\hline & & Coefficient. & $t$-Statistic & Coefficient. & $t$-Statistic \\
\hline \multicolumn{6}{|l|}{ Long-run } \\
\hline & $o p^{+}$ & 0.015 & 0.135 & -0.449 & $-1.783^{*}$ \\
\hline & $o p^{-}$ & 0.012 & 0.106 & -0.449 & $-1.847^{*}$ \\
\hline \multicolumn{6}{|l|}{ Short-run } \\
\hline & $\Delta e x(-1) \operatorname{or} \Delta s p(-1)$ & -0.028 & -1.503 & -0.027 & -1.481 \\
\hline & $\Delta e x(-2)$ & 0.002 & 0.110 & - & - \\
\hline & $\Delta e x(-3)$ & 0.038 & $2.069^{* *}$ & - & - \\
\hline & $\Delta o p^{+}$ & -0.007 & $-3.596^{* * *}$ & 0.035 & $2.349 * *$ \\
\hline & $\Delta o p^{+}(-1)$ & - & - & 0.035 & $2.414 * *$ \\
\hline & $\Delta o p^{-}$ & -0.005 & $-3.175^{* * *}$ & 0.037 & $3.393 * * *$ \\
\hline & $\Delta o p^{-}(-1)$ & -0.007 & $-4.041 * * *$ & 0.046 & $3.763 * * *$ \\
\hline & $\Delta o p^{-}(-2)$ & -0.001 & 0.399 & 0.025 & $2.071^{* *}$ \\
\hline & $\Delta o p^{-}(-3)$ & -0.004 & $-2.619 * * *$ & - & - \\
\hline & $\operatorname{ECT}(-1)$ & -0.002 & $-2.672 * * *$ & -0.006 & $-3.374 * * *$ \\
\hline
\end{tabular}




\begin{tabular}{lll}
\hline Breaks & No & No \\
Bounds F & 1.782 & 2.844 \\
Long-run asymmetry F & 0.922 & 0.043 \\
Short-run asymmetry F & $6.348^{* * *}$ & $5.877^{* *}$ \\
B-G LM test & 0.388 & 0.508 \\
B-P test & $114.402^{* * * *}$ & $143.56^{* * *}$ \\
RESET & 1.999 & 0.649 \\
CUSUM & Stable & Stable \\
CUSUM Squares & Unstable & Unstable \\
\hline
\end{tabular}

Note. B-G LM is Breusch-Godfrey LM autocorrelation test. B-P test is Breusch-Pagan heteroskedasticity test. HAC standard errors used. $*, * *, \& * * *$ respectively mean significance at $10 \%, 5 \%, \& 1 \%$.

\section{Conclusion}

China has emerged as one of the biggest energy consumers in the world. The country's crude oil consumption is estimated to be nearly one-third of OECD countries and is projected to rise to 18 million barrels per day by 2040 . On the basis of China's heavy energy-dependence, we analyse the role of crude oil prices movements on the country's exchange rate and stock markets using daily data. More importantly, we examined possibility of asymmetries in the impact of oil price on both markets using asymmetric ARDL approach. In addition, China's economy has witnessed several key structural events that when ignored, could adversely affect the result of our analysis. Hence, we account for structural breaks in testing for asymmetric oil price effects on both markets. The results suggest that oil price influences the exchange rate and stock price in China mainly in the short-run when daily data is used. These results are consistent whether or not we account for structural breaks in the methodology. However, evidence of cointegration only exists when structural breaks are included in the model which confirms that the structural events significantly alter the time paths of the US dollar-Renminbi rate and Shanghai index from their usual time paths over the analysis period. Evidence of short-run and long-run asymmetry is found for exchange rate when structural breaks are included whereas only short-run asymmetry persists when there are no breaks. For stock price, there is evidence of short-run asymmetry only when there are no structural breaks in the model. In general, our findings show that oil price appreciates the Renminbi significantly vis-à-vis the US dollar whether or not oil price increases or decreases in the short-run. Similarly, there is a short-run increase in the Shanghai index whether or not oil price increases or decreases. In light of these findings, the observed asymmetries in the influence of oil price on both variables are in magnitude terms only and do not relate to direction of impact. The main takeaway these results in terms of policy is that oil price seems to influence both markets mostly in the short-run and hence, short-term policies that affect both should fully consider oil-price's role.

\section{Author Contributions}

Ahmed, N.: Conceptualization, Resources, Validation, Writing - original draft, Formal analysis and Methodology. Dingchou, M.: Investigation, Project administration, Supervision. Qayyum A.: Data correction, Writing - Review \& Editing.

\section{Acknowledgements}

This paper received financial support for publication fee from the College of Finance and Economics, Gansu Agricultural University, China.

\section{Declaration of interests}

The authors declare that they have no known competing financial interests or personal relationships that could have influenced the work reported in this paper.

\section{References}

Adeniyi, O. A., Omisakin, D., Olusegun, A., Yaqub, J., \& Oyinlola, A. (2012). Oil price-exchange rate nexus in Nigeria: further evidence from an oil exporting economy. International Journal of Humanities and Social Science, 2(8), 113-121.

Al-Mudhaf, A., \& Goodwin, T.H. (1993). Oil shocks and oil stocks: evidence from the 1970s. Applied Economics, 25(2), 181-190. https://doi.org/10.1080/00036849300000023

Amano, R. A., \& van Norden, S. (1998). Oil prices and the rise and fall of the US real exchange rate. Journal of International Money and Finance, 17(2), 299-316. https://doi.org/10.1016/S0261-5606(98)00004-7 
Bai, S., \& Koong, K. S. (2018). Oil prices, stock returns, and exchange rates: Empirical evidence from China and the United States. The North American Journal of Economics and Finance, 44, 12-33. https://doi.org/10.1016/j.najef.2017.10.013

Basher, S. A., Haug, A. A., \& Sadorsky, P. (2012). Oil prices, exchange rates and emerging stock markets. Energy Economics, 34(1), 227-240. https://doi.org/10.1016/j.eneco.2011.10.005

Beckmann, J., \& Czudaj, R. (2013). Oil prices and effective dollar exchange rates. International Review of Economics \& Finance, 27, 621-636. https://doi.org/10.1016/j.iref.2012.12.002

Beckmann, J., Czudaj, R., \& Arora, V. (2017). The relationship between oil prices and exchange rates: theory and evidence. US Energy Information Administration Working Paper Series, 1-62.

Bénassy-Quéré, A., Mignon, V., \& Penot, A. (2007). China and the relationship between the oil price and the dollar. Energy Policy, 35(11), 5795-5805. https://doi.org/10.1016/j.enpol.2007.05.035

Benhabib, A., Kamel, S. M., \& Maliki, S. (2014). The relationship between oil price and the Algerian exchange rate. Topics in Middle Eastern and African Economies, 16(1), 127-141.

Bjørnland, H. C. (2009). Oil price shocks and stock market booms in an oil exporting country. Scottish Journal of Political Economy, 56(2), 232-254. https://doi.org/10.1111/j.1467-9485.2009.00482.x

Bohi, D. R. (1989). Energy Price Shocks and Macroeconomic Performance. Washington: Resources for the Future.

Broadstock, D. C., \& Filis, G. (2014). Oil price shocks and stock market returns: New evidence from the United States and China. Journal of International Financial Markets, Institutions and Money, 33, 417-433. https://doi.org/10.1016/j.intfin.2014.09.007

Caporale, G. M., Ali, F. M., \& Spagnolo, N. (2015). Oil price uncertainty and sectoral stock returns in China: A time-varying approach. China Economic Review, 34, 311-321. https://doi.org/10.1016/j.chieco.2014.09.008

Elyasiani, E., Mansur, I., \& Odusami, B. (2011). Oil price shocks and industry stock returns. Energy Economics, 33(5), 966-974. https://doi.org/10.1016/j.eneco.2011.03.013

Faria, J. R., Mollick, A. V., Albuquerque, P. H., \& León-Ledesma, M. A. (2009). The effect of oil price on China's exports. China Economic Review, 20(4), 793-805. https://doi.org/10.1016/j.chieco.2009.04.003

Filis, G., \& Chatziantoniou, I. (2014). Financial and monetary policy responses to oil price shocks: Evidence from oil-importing and oil-exporting countries. Review of Quantitative Finance and Accounting, 42(4), 709-729. https://doi.org/10.1007/s11156-013-0359-7

Filis, G., Degiannakis, S., \& Floros, C. (2011). Dynamic correlation between stock market and oil prices: The case of oil-importing and oil-exporting countries. International Review of Financial Analysis, 20(3), 152-164. https://doi.org/10.1016/j.irfa.2011.02.014

Ghouri, S. S. (2006). Assessment of the relationship between oil prices and US oil stocks. Energy Policy, 34(17), 3327-3333. https://doi.org/10.1016/j.enpol.2005.07.007

Hamilton, J. D. (1988, March). Are the macroeconomic effects of oil-price changes symmetric? A comment. In Carnegie-Rochester Conference Series on Public Policy (Vol. 28, pp. 369-378). North-Holland. https://doi.org/10.1016/0167-2231(88)90031-0

Hamilton, J. D. (2003). What is an oil shock?. Journal of Econometrics, 113(2), 363-398. https://doi.org/10.1016/S0304-4076(02)00207-5

Hasanov, F., \& Samadova, I. (2010). The impact of real exchange rate on non-oil exports: The case of Azerbaijan. MPRA Paper, 29556, 1-19. https://doi.org/10.2139/ssrn.1784286

IEA. (2020). Oil and petroleum products explained. Retrieved from https://www.eia.gov/energyexplained/oil-and-petroleum-products/use-of-oil.php

Jahan-Parvar, M. R., \& Mohammadi, H. (2011). Oil prices and real exchange rates in oil-exporting countries: A bounds testing approach. The Journal of Developing Areas, 313-322. https://doi.org/10.1353/jda.2011.0020

Jones, C. M., \& Kaul, G. (1996). Oil and the stock markets. The journal of Finance, 51(2), 463-491. https://doi.org/10.1111/j.1540-6261.1996.tb02691.x

Ju, K., Zhou, D., Zhou, P. \& Wu, J. (2014). Macroeconomic effects of oil price shocks in China: An empirical study based on Hilbert-Huang transform and event study. Applied Energy, 136, 1053-1066. 
https://doi.org/10.1016/j.apenergy.2014.08.037

Kang, W., Ratti, R. A., \& Yoon, K. H. (2014). The impact of oil price shocks on US bond market returns. Energy Economics, 44, 248-258. https://doi.org/10.1016/j.eneco.2014.04.009

Khraief, N., Shahbaz, M., Mahalik, M. K., \& Bhattacharya, M. (2021). Movements of oil prices and exchange rates in China and India: New evidence from wavelet-based, non-linear, autoregressive distributed lag estimations. Physica A: Statistical Mechanics and Its Applications, 563, 125423. https://doi.org/10.1016/j.physa.2020.125423

Kilian, L. (2009). Not All Oil Price Shocks Are Alike: Disentangling Demand and Supply Shocks in the Crude Oil Market. American Economic Review, 19, 1053-69. https://doi.org/10.1257/aer.99.3.1053

Kilian, L., \& Park, C. (2009). The impact of oil price shocks on the US stock market. International Economic Review, 50(4), 1267-1287. https://doi.org/10.1111/j.1468-2354.2009.00568.x

Kumar, S. (2019). Asymmetric impact of oil prices on exchange rate and stock prices. The Quarterly Review of Economics and Finance, 72, 41-51. https://doi.org/10.1016/j.qref.2018.12.009

Kutan, A.M. \& Wyzan, M.L. (2005). Explaining the real exchange rate in Kazakhstan, 1996-2003: Is Kazakhstan vulnerable to the Dutch disease? Economic Systems, 29(2), 242-255. https://doi.org/10.1016/j.ecosys.2005.03.009

Lambertides, N., Savva, C. S., \& Tsouknidis, D. A. (2017). The effects of oil price shocks on US stock order flow imbalances and stock returns. Journal of International Money and Finance, 74, 137-146. https://doi.org/10.1016/j.jimonfin.2017.03.008

Lee, K., Ni, S., \& Ratti, R. A. (1995). Oil shocks and the macro-economy: The role of price variability. The Energy Journal, 16, 39-56. https://doi.org/10.5547/ISSN0195-6574-EJ-Vol16-No4-2

Lin, C. C., Fang, C. R., \& Cheng, H. P. (2010). Relationships between oil price shocks and stock market: an empirical analysis from Greater China. China Economic Journal, 3(3), 241-254. https://doi.org/10.1080/17538963.2010.562031

Lizardo, R. A., \& Mollick, A. V. (2010). Oil price fluctuations and US dollar exchange rates. Energy Economics, 32(2), 399-408. https://doi.org/10.1016/j.eneco.2009.10.005

Meidan, M. (2020). China's oil demand in the wake of Covid-19. Retrieved from https://www.oxfordenergy.org/publications/chinas-oil-demand-in-the-wake-of-covid-19/

Mokni, K. (2020). Time-varying effect of oil price shocks on the stock market returns: Evidence from oil-importing and oil-exporting countries. Energy Reports, 6, 605-619. https://doi.org/10.1016/j.egyr.2020.03.002

Mollick, A. V., \& Assefa, T. A. (2013). US stock returns and oil prices: The tale from daily data and the 2008-2009 financial crisis. Energy Economics, 36, 1-18. https://doi.org/10.1016/j.eneco.2012.11.021

Mork, K. A. (1989). Oil \& the macroeconomy when prices go up and down: An extension of Hamilton's results. Journal of political Economy, 97(3), 740-744. https://doi.org/10.1086/261625

Nandha, M., \& Faff, R. (2008). Does oil move equity prices? A global view. Energy Economics, 30(3), 986-997. https://doi.org/10.1016/j.eneco.2007.09.003

Olomola, P. A., \& Adejumo, A. V. (2006). Oil price shock and macroeconomic activities in Nigeria. International Research Journal of Finance and Economics, 3(1), 28-34.

Ou, B., Zhang, X., \& Wang, S. (2012). How does China's macro-economy response to the world crude oil price shock: A structural dynamic factor model approach. Computers \& Industrial Engineering, 63(3), 634-640. https://doi.org/10.1016/j.cie.2012.03.012

Qiang, W., Lin, A., Zhao, C., Liu, Z., Liu, M., \& Wang, X. (2019). The impact of international crude oil price fluctuation on the exchange rate of petroleum-importing countries: A summary of recent studies. Natural Hazards, 95(1-2), 227-239. https://doi.org/10.1007/s11069-018-3501-y

Qianqian, Z. (2011). The impact of international oil price fluctuation on China's economy. Energy Procedia, 5 , 1360-1364. https://doi.org/10.1016/j.egypro.2011.03.235

Rautava, J. (2004). The role of oil prices and the real exchange rate in Russia's economy-A cointegration approach. Journal of Comparative Economics, 32(2), 315-327. https://doi.org/10.1016/j.jce.2004.02.006 
Ritchie, H., \& Roser, M. (2020). China: Energy country profile. Retrieved from https://ourworldindata.org/energy

Sakaki, H. (2019). Oil price shocks and the equity market: Evidence for the S\&P 500 sectoral indices. Research in International Business and Finance, 49, 137-155. https://doi.org/10.1016/j.ribaf.2019.03.001

Salisu, A. A., \& Oloko, T. F. (2015). Modeling oil price-US stock nexus: A VARMA-BEKK-AGARCH approach. Energy Economics, 50, 1-12. https://doi.org/10.1016/j.eneco.2015.03.031

Shin, Y., Yu, B., \& Greenwood-Nimmo, M. (2014). Modelling asymmetric cointegration and dynamic multipliers in a nonlinear ARDL framework. In Festschrift in honor of Peter Schmidt (281-314). Springer, New York, NY. https://doi.org/10.1007/978-1-4899-8008-3_9

Suleiman, H., \& Muhammad, Z. (2011). The real exchange rate of an oil exporting economy: Empirical evidence from Nigeria (No. 72). FIW Working Paper.

Tian, M., Li, W., \& Wen, F. (2021). The dynamic impact of oil price shocks on the stock market and the USD/RMB exchange rate: Evidence from implied volatility indices. The North American Journal of Economics and Finance, 55, 101310. https://doi.org/10.1016/j.najef.2020.101310

Tiwari, A. K., Mutascu, M. I., \& Albulescu, C. T. (2013). The influence of the international oil prices on the real effective exchange rate in Romania in a wavelet transform framework. Energy Economics, 40, 714-733. https://doi.org/10.1016/j.eneco.2013.08.016

Turhan, M.I., Sensoy, A. \& Hacihasanoglu, E. (2014). A comparative analysis of the dynamic relationship between oil prices and exchange rates. Journal of International Financial Markets, Institutions and Money, 32, 397-414. https://doi.org/10.1016/j.intfin.2014.07.003

Wang, Y., Wu, C., \& Yang, L. (2013). Oil price shocks and stock market activities: Evidence from oil-importing and oil-exporting countries. Journal of Comparative Economics, 41(4), 1220-1239. https://doi.org/10.1016/j.jce.2012.12.004

Wei, Y., \& Guo, X. (2017). Oil price shocks and China's stock market. Energy, 140, 185-197. https://doi.org/10.1016/j.energy.2017.07.137

Wei, Y., Qin, S., Li, X., Zhu, S. \& Wei, G. (2019). Oil price fluctuation, stock market and macroeconomic fundamentals: Evidence from China before and after the financial crisis. Finance Research Letters, 30, 23-29. https://doi.org/10.1016/j.frl.2019.03.028

Xiao, J., Zhou, M., Wen, F., \& Wen, F. (2018). Asymmetric impacts of oil price uncertainty on Chinese stock returns under different market conditions: Evidence from oil volatility index. Energy Economics, 74, 777-786. https://doi.org/10.1016/j.eneco.2018.07.026

Zhang, C., \& Chen, X. (2011). The impact of global oil price shocks on China's stock returns: Evidence from the ARJI (-ht)-EGARCH model. Energy, 36(11), 6627-6633. https://doi.org/10.1016/j.energy.2011.08.052

Zhu, H., Su, X., Guo, Y., \& Ren, Y. (2016). The Asymmetric Effects of Oil Price Shocks on the Chinese stock market: Evidence from a quantile impulse response perspective. Sustainability, 8(8), 766. https://doi.org/10.3390/su8080766

\section{Copyrights}

Copyright for this article is retained by the author(s), with first publication rights granted to the journal.

This is an open-access article distributed under the terms and conditions of the Creative Commons Attribution license (http://creativecommons.org/licenses/by/4.0/). 